\title{
Epidemiology and risk factors of needlestick injuries among healthcare workers in Iran: a systematic reviews and meta-analysis
}

Soheil Hassanipour ${ }^{1}$, Mojtaba Sepandi², Reza Tavakkol ${ }^{3}$, Mousa Jabbari ${ }^{4}$, Hadiseh Rabiei ${ }^{5}$, Mahdi Malakoutikhah ${ }^{6}$, Mohammad Fathalipour ${ }^{2}$ and Gholamhossein Pourtaghi ${ }^{2^{*}}$

\begin{abstract}
Background: Occupational contact with blood and body fluids poses a significant risk to healthcare workers. The aim of this systematic review is to investigate the epidemiology and risk factors affecting needlestick injuries (NSI) in healthcare personnel in Iran.

Methods: In March 2020, researchers studied six international databases such as Medline/PubMed, ProQuest, ISI/ WOS, Scopus, Embase, and Google Scholar for English papers and two Iranian databases (Maglran and SID) for Persian papers. Joanna Briggs Institute (JBI) Critical Appraisal Checklist was used to assess quality of studies. The method of reporting was based on the Preferred Reporting Items for Systematic Reviews and Meta-Analysis (PRIS MA) statement.

Results: A total of 43 articles were included in the analysis. Results showed that females $(\mathrm{OR}=1.30,95 \% \mathrm{Cl} 1.06-$ 1.58 , $P$ value $=0.009)$, younger age $(\mathrm{OR}=2.75,95 \% \mathrm{Cl} 2.27-3.33, P$ value $<0.001$, rotated shift workers $(\mathrm{OR}=2.16$, $95 \% \mathrm{Cl} 1.47-3.15, P$ value $<0.001)$, not attending training courses $(\mathrm{OR}=1.30,95 \% \mathrm{Cl} 1.07-1.56, P$ value $=0.006)$, working in the surgery ward $(\mathrm{OR}=1.83,95 \% \mathrm{Cl} 1.33-2.50, P$ value $<0.001)$, less work experience $(\mathrm{OR}=1.43,95 \%$ Cl 1.04-1.95, $P$ value $=0.025$ ) apposed a greater risk factors for NSI among healthcare workers.

Conclusion: Based on the results of this review, factors such as young age, less work experience, work shift, and female gender are considered as strong risk factors for NSI injury in Iran. Preventive measures including education programs can reduce the burden of NSI among healthcare personnel.
\end{abstract}

Keywords: Needlestick injuries, Healthcare workers, Systematic review, Meta-analysis, Iran

\footnotetext{
* Correspondence: pourtaghi@bmsu.ac.ir

${ }^{2}$ Health Research Center, Life Style Institute, Baqiyatallah University of

Medical Sciences, Tehran, Iran

Full list of author information is available at the end of the article
}

(c) The Author(s). 2021 Open Access This article is licensed under a Creative Commons Attribution 4.0 International License, which permits use, sharing, adaptation, distribution and reproduction in any medium or format, as long as you give appropriate credit to the original author(s) and the source, provide a link to the Creative Commons licence, and indicate if changes were made. The images or other third party material in this article are included in the article's Creative Commons licence, unless indicated otherwise in a credit line to the material. If material is not included in the article's Creative Commons licence and your intended use is not permitted by statutory regulation or exceeds the permitted use, you will need to obtain permission directly from the copyright holder. To view a copy of this licence, visit http://creativecommons.org/licenses/by/4.0/. The Creative Commons Public Domain Dedication waiver (http://creativecommons.org/publicdomain/zero/1.0/) applies to the data made available in this article, unless otherwise stated in a credit line to the data. 


\section{Introduction}

Needlestick injuries (NSI) are injuries caused by a needle head or a piece of broken ampule or other sharp object contaminated with blood or body secretions [1]. Occupational contact with blood and body fluids, followed by blood-borne infections, poses a significant risk to healthcare personnel [2]. At least 20 pathogenic pathogens can be transmitted following these injuries $[3,4]$. Worldwide, about $25 \%$ of Hepatitis B virus (HBV) and Hepatitis $\mathrm{C}$ virus (HCV) infections and about $2.5 \%$ of HIV infections occur among healthcare workers due to NSI [5-7]. According to the World Health Organization, about 3 million out of the 35 million healthcare workers are exposed to NSI each year [8]. The annual economic burden of NSI was estimated to be $\$ 302$ million in Japan [9]. The annual incidence of NSI was estimated at 20.5 per 1000 nurses and 16 per 1000 physicians in Poland. Overall, there were approximately 13,576 cases of NSI damage in Poland in 2014 [10].

Ghanei Gheshlagh et al.'s study showed the prevalence of needle head injury among healthcare personnel in Iran is $42.5 \%$, and this rate is higher in females than males (47 vs. 42\%) [11]. NSI-related risk factors have not yet been properly identified in Iran. Studies have identified factors such as excessive and unnecessary injections, poor personnel training, female gender, high workloads, and excessive fatigue especially at nighttime as the most important causes of NSI [7, 12-17]. Moreover, a

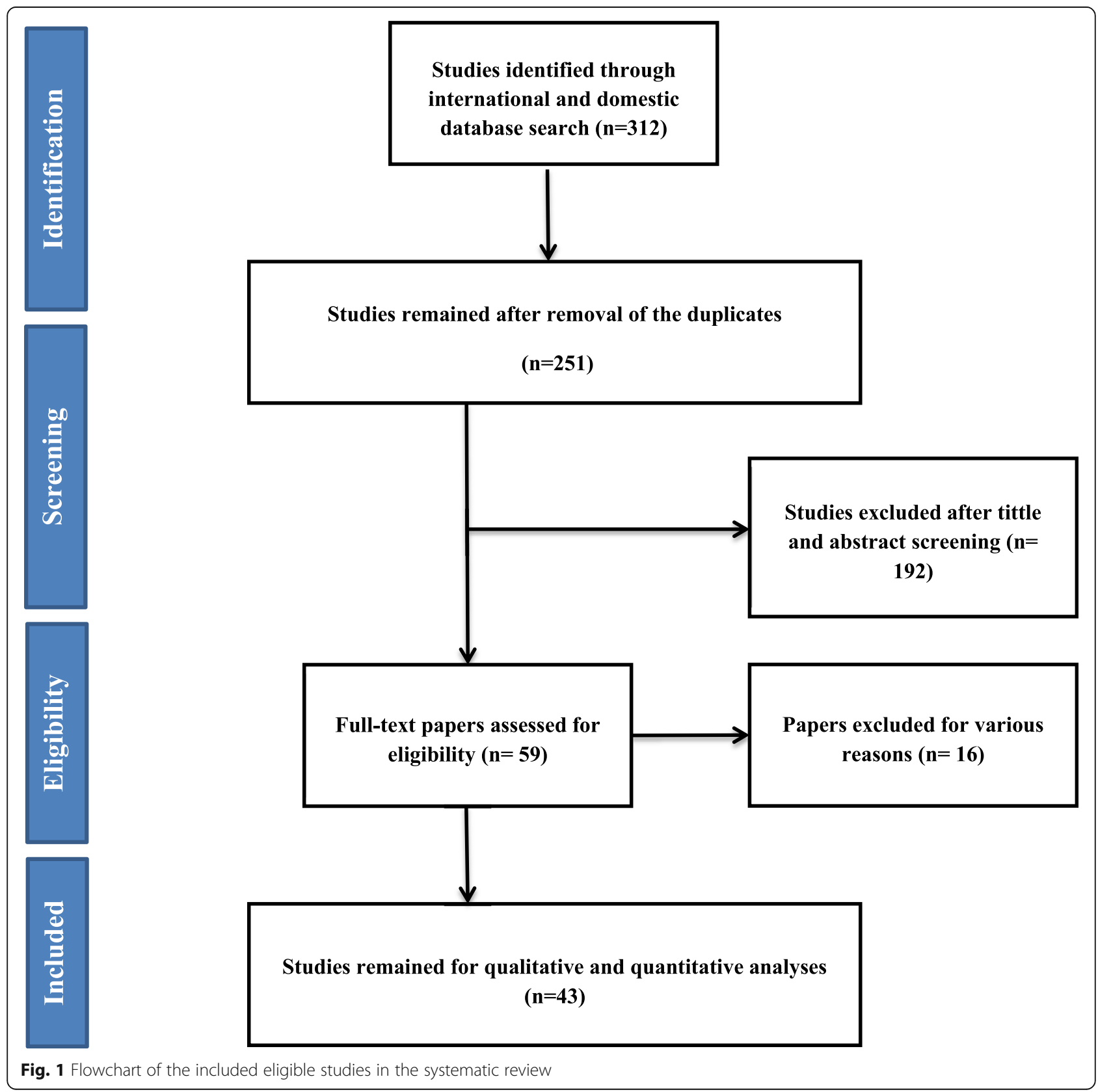


Table 1 Descriptive data of included studies

\begin{tabular}{|c|c|c|c|c|c|c|c|c|c|}
\hline Author, Year & Province & Design & $\begin{array}{l}\text { Year } \\
\text { of } \\
\text { study }\end{array}$ & Population & Language & $\begin{array}{l}\text { Sample } \\
\text { size }\end{array}$ & Prevalence & Summary data for each study & $\begin{array}{l}\text { Level } \\
\text { of } \\
\text { quality } \\
\end{array}$ \\
\hline Safaeian, 2019 [58] & Isfahan & CSS & 2016 & $\mathrm{HCW}$ & Persian & 200 & NR & $\begin{array}{l}\text { Main risk factors related to NSI: } \\
\text { Social support [odds ratio }(\mathrm{OR})= \\
0.85, P<0.001 \text { ], psychosocial } \\
\text { demand }(\mathrm{OR}=1.07, P=0.001) \text {, } \\
\text { gender }(\mathrm{OR}=0.44, P=0.010) \text {, the } \\
\text { dominant hand }(\mathrm{OR}=0.52, P= \\
\text { 0.040), and participation in } \\
\text { educational classes }(\mathrm{OR}=0.24 ; P= \\
0.005)\end{array}$ & High \\
\hline $\begin{array}{l}\text { Bagheri } \\
\text { Hosseinabadi, } \\
2019[28]\end{array}$ & $\begin{array}{l}\text { Babol, } \\
\text { Kerman, } \\
\text { Mashhad, } \\
\text { and } \\
\text { Hamedan. }\end{array}$ & CSS & $\begin{array}{l}2015- \\
2016\end{array}$ & $\mathrm{HCW}$ & English & 616 & NR & $\begin{array}{l}\text { Needlestick injuries showed a } \\
\text { significant relation with age gender, } \\
\text { work experience, and number of } \\
\text { shifts in a month }\end{array}$ & High \\
\hline $\begin{array}{l}\text { Salmanzadeh, } \\
2016 \text { [59] }\end{array}$ & $\begin{array}{l}\text { Dasht-e- } \\
\text { Azadegan }\end{array}$ & CSS & 2011 & $\mathrm{HCW}$ & English & 377 & 18.3 & $\begin{array}{l}\text { The highest frequency of needlestick } \\
\text { injuries was observed at the night } \\
\text { shifts }(47.8 \%) \text { and at the end of the } \\
\text { shifts }(64.70 \%) \text {. }\end{array}$ & Medium \\
\hline $\begin{array}{l}\text { Jahangiri, } 2016 \\
\text { [15] }\end{array}$ & Shiraz & CSS & 2014 & HCW & English & 168 & 76.0 & $\begin{array}{l}\text { A statistically significant relationship } \\
\text { was found between the occurrence } \\
\text { of NSIs and hours worked/week, sex, } \\
\text { and frequency of shifts/month. }\end{array}$ & High \\
\hline $\begin{array}{l}\text { Mahmoudi, } 2015 \\
\text { [48] }\end{array}$ & Tehran & CSS & 2012 & $\mathrm{HCW}$ & English & 100 & 41.0 & $\begin{array}{l}\text { The relationship between } \\
\text { occupational exposure to hospital } \\
\text { sharp tools and age, experience, } \\
\text { education, and place of work was } \\
\text { significant with } P=0.006,0.017 \text {, } \\
0.027 \text {, and } 0.008 \text {, respectively. }\end{array}$ & Medium \\
\hline Izadi, 2015 [45] & Tehran & CSS & $\begin{array}{l}2011- \\
2012\end{array}$ & $\mathrm{HCW}$ & English & 309 & 26.8 & $\begin{array}{l}\text { The incidence rate of NSIs in the } \\
\text { HCWs on rotational shift work (90.4\%) } \\
\text { was higher than that among their } \\
\text { counterparts on fixed shift work } \\
(9.6 \%) \text {. }\end{array}$ & Medium \\
\hline $\begin{array}{l}\text { Hajivandi, } 2015 \\
\text { [40] }\end{array}$ & Bushehr & CSS & 2013 & $\mathrm{HCW}$ & Persian & 68 & 58.8 & $\begin{array}{l}\text { Sharp injury events occurred more } \\
\text { frequently at the hours from 11:00 to } \\
\text { 14:00 and after 16:00. }\end{array}$ & Medium \\
\hline $\begin{array}{l}\text { Ghasemzadeh, } \\
2015 \text { [37] }\end{array}$ & Hormozgan & CSS & $\begin{array}{l}2012- \\
2013\end{array}$ & SN & English & 377 & 39.3 & $\begin{array}{l}\text { A significant relationship was found } \\
\text { between workplace and the NSI. } \\
\text { Sixty-three }(42.6 \%) \text { of the injured stu- } \\
\text { dents were interns in the emergency } \\
\text { department ( } P \text { value }<0.001) \text {. }\end{array}$ & Medium \\
\hline Balouchi, 2015 [29] & Kerman & CSS & $\begin{array}{l}2014- \\
2015\end{array}$ & HCW & English & 200 & 64.0 & $\begin{array}{l}\text { The results of Spearman's correlation } \\
\text { coefficient test showed no } \\
\text { statistically significant relationships } \\
\text { between the history of needlestick } \\
\text { injuries and variables including work } \\
\text { experience, age, and the number of } \\
\text { shifts per month. }\end{array}$ & Medium \\
\hline $\begin{array}{l}\text { Mirzaei-Alavijeh, } \\
2014 \text { [50] }\end{array}$ & Kermanshah & CSS & 2013 & $\mathrm{HCW}$ & English & 58 & 41.4 & $\begin{array}{l}\text { Logistic regression showed that sex } \\
(\mathrm{OR}=2.872) \text { and job stress }(\mathrm{OR}= \\
1.503) \text { could predict NSI. }\end{array}$ & Medium \\
\hline $\begin{array}{l}\text { Mehrdad, } 2014 \\
\text { [49] }\end{array}$ & Tehran & CSS & 2012 & $\mathrm{HCW}$ & English & 339 & 58.1 & $\begin{array}{l}\text { There is a significant association } \\
\text { between increasing psychosocial } \\
\text { factors at work and exposure to } \\
\text { blood-borne pathogens. }\end{array}$ & High \\
\hline Lakbala, 2014 [46] & Hormozgan & CSS & 2013 & $\mathrm{HCW}$ & English & 215 & 89.3 & $\begin{array}{l}\text { The commonest reasons for non- } \\
\text { compliance with NSI local protocols } \\
\text { were not being sure of the local pro- } \\
\text { tocols }(20.4 \%) \text { and prolonged oper- } \\
\text { ation so unable to leave operation }\end{array}$ & Medium \\
\hline
\end{tabular}


Table 1 Descriptive data of included studies (Continued)

\begin{tabular}{|c|c|c|c|c|c|c|c|c|c|}
\hline Author, Year & Province & Design & $\begin{array}{l}\text { Year } \\
\text { of } \\
\text { study }\end{array}$ & Population & Language & $\begin{array}{l}\text { Sample } \\
\text { size }\end{array}$ & Prevalence & Summary data for each study & $\begin{array}{l}\text { Level } \\
\text { of } \\
\text { quality }\end{array}$ \\
\hline & & & & & & & & table (17.3\%). & \\
\hline $\begin{array}{l}\text { Ghanei Gheshlagh, } \\
2014 \text { [35] }\end{array}$ & Saqqez & CSS & 2014 & $\mathrm{HCW}$ & Persian & 120 & 44.2 & $\begin{array}{l}\text { Comparing with other HCWs, those } \\
\text { with needlestick injury were younger } \\
(P=0.01) \text { and had less work } \\
\text { experience }(P=0.03)\end{array}$ & Medium \\
\hline Shoghli, 2013 [62] & Zanjan & CSS & 2011 & HCW & Persian & 600 & 53.6 & $\begin{array}{l}\text { The frequency of NSI had a reverse } \\
\text { relationship with age and work } \\
\text { history, and it was significantly higher } \\
\text { in male workers. }\end{array}$ & High \\
\hline Rezaei, 2013 [57] & Tehran & CSS & $\begin{array}{l}2006- \\
2009\end{array}$ & HCW & English & 514 & 26.0 & $\begin{array}{l}\text { There was no statistically significant } \\
\text { difference in demographic variables } \\
\text { except in work experience between } \\
\text { two groups. }\end{array}$ & Medium \\
\hline Gholami, 2013 [38] & Neyshabur & CSS & 2011 & HCW & English & 384 & 32.0 & $\begin{array}{l}\text { Age }(\mathrm{OR}=0.551,95 \% \mathrm{Cl} 0.325-0.934) \\
\text { and number of shifts per month } \\
(\mathrm{OR}=2.404,95 \% \mathrm{Cl} 1.389-4.160) \text { were } \\
\text { found to be significantly associated } \\
\text { with occurrence of needlestick and } \\
\text { sharps injuries. }\end{array}$ & Medium \\
\hline $\begin{array}{l}\text { Adib-Hajbaghery, } \\
2013 \text { [22] }\end{array}$ & Kashan & CSS & 2012 & HCW & English & 298 & 38.3 & $\begin{array}{l}32.5 \% \text { of injuries from sharp } \\
\text { instruments occurred in the morning } \\
\text { shift. }\end{array}$ & High \\
\hline Ehsani, 2013 [33] & Tehran & CSS & 2009 & $\mathrm{HCW}$ & English & 328 & 45.12 & $\begin{array}{l}\text { There were significant associations } \\
\text { between the staff age as well as the } \\
\text { ward with the extent of injuries. }\end{array}$ & Medium \\
\hline Tirgar, 2012 [63] & Babol & CSS & 2010 & $\mathrm{HCW}$ & Persian & 340 & 59.7 & $\begin{array}{l}\text { Statistical analysis showed that age, } \\
\text { work experience, and received } \\
\text { educational course could be } \\
\text { associated with NSI. }\end{array}$ & Medium \\
\hline Sharifian, 2012 [60] & Tehran & CSS & $\begin{array}{l}2008- \\
2009\end{array}$ & $\mathrm{HCW}$ & Persian & 350 & 19.7 & $\begin{array}{l}\text { There was no statistically difference } \\
\text { between job stress and NSI ( } P= \\
0.374) \text {. }\end{array}$ & Medium \\
\hline $\begin{array}{l}\text { Hashemi, } 2012 \\
\text { [41] }\end{array}$ & Hamedan & CSS & 2010 & HCW & Persian & 700 & 24.1 & $\begin{array}{l}\text { Statistical analysis showed that } \\
\text { gender (female) and age group [30- } \\
\text { 34] could be associated with NSI. }\end{array}$ & Medium \\
\hline $\begin{array}{l}\text { Ghannad, } 2012 \\
{[36]}\end{array}$ & Hamedan & CSS & $\begin{array}{l}2007- \\
2008\end{array}$ & HCW & English & 89 & $N R$ & $\begin{array}{l}\text { The most exposed age group was } \\
25-34 \text { years (51.6\%). }\end{array}$ & Medium \\
\hline Bijani, 2012 [30] & Qazvin & CSS & 2009 & $\mathrm{HCW}$ & Persian & 246 & 31.3 & $\begin{array}{l}\text { Statistical analysis showed that work } \\
\text { load could be associated with NSI. }\end{array}$ & Medium \\
\hline Shiva, 2011 [61] & Tehran & CSS & 2009 & PHCP & English & 355 & 49.3 & $\begin{array}{l}\text { Needlestick injuries are common } \\
\text { among pediatric healthcare } \\
\text { personnel, and their knowledge } \\
\text { about prevention strategies is } \\
\text { suboptimal. }\end{array}$ & Medium \\
\hline $\begin{array}{l}\text { Mohammadi, } 2011 \\
\text { [51] }\end{array}$ & Qazvin & CSS & 2008 & HCW & English & 138 & 52.9 & $\begin{array}{l}\text { The rate of NSI was significantly } \\
\text { higher in the general surgery ward. }\end{array}$ & High \\
\hline Bijani, 2011 [31] & Qazvin & CSS & 2009 & HCW & Persian & 172 & 32.0 & $\begin{array}{l}\text { There was no statistically significant } \\
\text { relationship between needlestick } \\
\text { injuries and educational level, gender, } \\
\text { and related training courses, but } \\
\text { there was a statistically significant } \\
\text { relationship between the injuries and } \\
\text { the number of continuous shifts. }\end{array}$ & Medium \\
\hline Azadi, 2011 [27] & Tehran & CSS & 2009 & $\mathrm{HCW}$ & English & 111 & 45.9 & $\begin{array}{l}\text { Statistical analysis showed that } \\
\text { gender (female), age group [26-30], } \\
\text { and HBV vaccination could be } \\
\text { associated with NSI. }\end{array}$ & Medium \\
\hline
\end{tabular}


Table 1 Descriptive data of included studies (Continued)

\begin{tabular}{|c|c|c|c|c|c|c|c|c|c|}
\hline Author, Year & Province & Design & $\begin{array}{l}\text { Year } \\
\text { of } \\
\text { study }\end{array}$ & Population & Language & $\begin{array}{l}\text { Sample } \\
\text { size }\end{array}$ & Prevalence & Summary data for each study & $\begin{array}{l}\text { Level } \\
\text { of } \\
\text { quality } \\
\end{array}$ \\
\hline Moradi, 2010 [52] & Bahar & CSS & 2008 & HCW & Persian & 182 & 48.9 & $\begin{array}{l}\text { The risk of occupational injuries } \\
\text { increased as the work experience } \\
\text { increased (OR }=1.07, \mathrm{Cl}=1.03-1.12) \text {. } \\
\text { There was no significant relationship } \\
\text { between employees' sex and age, } \\
\text { and occupational injuries. }\end{array}$ & Medium \\
\hline Heidari, 2010 [42] & $\begin{array}{l}\text { Borujen and } \\
\text { Lordegan }\end{array}$ & CSS & $\begin{array}{l}2007- \\
2008\end{array}$ & HCW & Persian & 77 & 45.4 & $\begin{array}{l}\text { The needlestick exposure was not } \\
\text { significantly different between males } \\
\text { and females. }\end{array}$ & Medium \\
\hline Gholami, 2010 [39] & Urmia & CSS & 2008 & HCW & Persian & 400 & 26.7 & $\begin{array}{l}\text { Needlestick injuries in females and } \\
\text { males were } 28 \% \text { and } 24 \% \text {, } \\
\text { respectively. Most of the injuries were } \\
\text { created by needle ( } 47.3 \%) \text { and } \\
\text { anjiocat needle (19.9\%). }\end{array}$ & Medium \\
\hline $\begin{array}{l}\text { Galougahi, } 2010 \\
{[34]}\end{array}$ & Tehran & CSS & 2008 & HCW & English & 158 & 56.9 & $\begin{array}{l}\text { There was no relationship between } \\
\text { age, gender, years of professional life, } \\
\text { and education level, and NSI. }\end{array}$ & Medium \\
\hline $\begin{array}{l}\text { Mohammadnejad, } \\
2010 \text { [43] }\end{array}$ & Tehran & CSS & 2008 & HCW & Persian & 218 & 43.1 & $\begin{array}{l}\text { Statistical analysis showed that work } \\
\text { experience could be associated with } \\
\text { NSI. }\end{array}$ & Medium \\
\hline $\begin{array}{l}\text { Rakhshani, } 2009 \\
{[56]}\end{array}$ & Zahedan & CSS & 2007 & HCW & Persian & 231 & 64.9 & $\begin{array}{l}\text { Statistical analysis showed that } \\
\text { education level and work experience } \\
\text { could be associated with NSI. }\end{array}$ & High \\
\hline Abdi, 2009 [21] & Jahrom & CSS & $\begin{array}{l}2006- \\
2007\end{array}$ & HCW & Persian & 298 & 48.3 & $\begin{array}{l}\text { Most of the NSIs were related to } \\
\text { HCWs with rotated working shifts.. }\end{array}$ & Medium \\
\hline $\begin{array}{l}\text { Mohammadnejad, } \\
2009 \text { [44] }\end{array}$ & Tehran & CSS & 2006 & HCW & Persian & 68 & 47.0 & $\begin{array}{l}\text { There were significant associations } \\
\text { between the staff age as well as the } \\
\text { work experience with the extent of } \\
\text { injuries. }\end{array}$ & Medium \\
\hline $\begin{array}{l}\text { Jonaidi Jafari, } 2008 \\
\text { [54] }\end{array}$ & Tehran & CSS & 2007 & HCW & Persian & 613 & 32.7 & $\begin{array}{l}\text { There was significant associations } \\
\text { between the workplace section and } \\
\text { NSI. }\end{array}$ & Medium \\
\hline Lotfi, 2008 [47] & Astara & CSS & 2006 & HCW & Persian & 90 & 67.0 & $\begin{array}{l}\text { Multiple logistic regression analysis } \\
\text { showed that the most important risk } \\
\text { factor for needlestick injuries was } \\
\text { working night shifts, (OR } 2.5,95 \% \mathrm{Cl} \\
1.5-4.8) \text {. Other important risk factor } \\
\text { including lack of training on such } \\
\text { injuries (OR 1.89, } 95 \% \mathrm{Cl} 1.1-3.4 \text { ), } \\
\text { number of patients attended daily or } \\
\text { nightly (OR 1.81, 95\% Cl 1.1-2.8), and } \\
\text { recapping needles (OR 1.67, 95\% Cl } \\
1.1-2.3 \text { ). }\end{array}$ & Medium \\
\hline Askarian, 2008 [24] & Fars & CSS & $\begin{array}{l}2006- \\
2007\end{array}$ & HCW & English & 2118 & 35.2 & $\begin{array}{l}\text { NSIs were independently associated } \\
\text { with gender, professional level, and } \\
\text { hospital location. }\end{array}$ & High \\
\hline $\begin{array}{l}\text { Ebrahimi, } \\
2007[32]\end{array}$ & Shahroud & CSS & 2005 & HCW & English & 180 & 63.3 & $\begin{array}{l}\text { There were significant associations } \\
\text { between the staff gender as well as } \\
\text { the work experience and the extent } \\
\text { of injuries. }\end{array}$ & Medium \\
\hline Azadi, 2007 [26] & Tehran & CSS & 2005 & $\mathrm{HCW}$ & Persian & 111 & 46.0 & $\begin{array}{l}\text { Statistical analysis showed that } \\
\text { gender (female), age, and work } \\
\text { experience was associated with NSIs. }\end{array}$ & Medium \\
\hline Vahedi, 2006 [64] & Kurdistan & CSS & 2004 & HCW & Persian & 847 & 43.5 & $\begin{array}{l}\text { There was significant associations } \\
\text { between the work load and NSI. }\end{array}$ & Medium \\
\hline $\begin{array}{l}\text { Nejadrahim, } 2005 \\
\text { [55] }\end{array}$ & Urmia & CSS & 2004 & HCW & Persian & 434 & 52.5 & $\begin{array}{l}57.3 \% \text { of women and } 45.3 \% \text { of men } \\
\text { had at least } 1 \text { event of NSI in the last } \\
\text { year which showed a meaningful }\end{array}$ & Medium \\
\hline
\end{tabular}


Table 1 Descriptive data of included studies (Continued)

\begin{tabular}{|c|c|c|c|c|c|c|c|c|c|}
\hline Author, Year & Province & Design & $\begin{array}{l}\text { Year } \\
\text { of } \\
\text { study }\end{array}$ & Population & Language & $\begin{array}{l}\text { Sample } \\
\text { size }\end{array}$ & Prevalence & Summary data for each study & $\begin{array}{l}\text { Level } \\
\text { of } \\
\text { quality }\end{array}$ \\
\hline & & & & & & & & statistical difference $(P$ value $=0.015)$ & \\
\hline $\begin{array}{l}\text { Nazmieh, } \\
2005 \text { [54] }\end{array}$ & Yazd & CSS & $\begin{array}{l}2003- \\
2004\end{array}$ & HCW & Persian & 1020 & 38.7 & $\begin{array}{l}\text { There were significant statistical } \\
\text { correlations between the variables of } \\
\text { the injuries and age, as well as the } \\
\text { injuries with occupational groups } \\
\text { and work settings ( } P=0.04,0.000 \text {, } \\
\text { and } 0.000) \text {, respectively. }\end{array}$ & Medium \\
\hline
\end{tabular}

HCW healthcare worker, NSI needlestick injury, CSS cross-sectional study, SN student nurse, NR not reported, PHCP Pediatric healthcare personnel

systematic review found age, level of education, number of shifts per month, and history of training courses for individuals as factors influencing NSI. Several psychological problems in healthcare personnel are attributable to NSI that impose heavy costs on medical systems [18].

Many of NSIs are a source of infections are not reported due to fear of staff as well as lack of proper awareness. A few existing meta-analyses have only investigated the prevalence of NSI in medical personnel in Iran [19, 20]. Therefore, the aim of this systematic review is to investigate the epidemiology and risk factors affecting NSI in healthcare personnel in Iran.

\section{Methods}

\section{Setting}

The present study is a systematic review and metaanalysis of risk factors associated with NSI in medical personnel in Iran. The study was designed and conducted in 2020. The method of reporting the present study was based on the Preferred Reporting Items for Systematic Reviews and Meta-Analysis (PRISMA) statement.

\section{Search strategy}

Six international databases including Medline/PubMed (http://www.ncbi.nlm.nih.gov), ProQuest (https://www. proquest.com/index), ISI/WOS (http://www. webofknowledge.com), Scopus (http://www.scopus.com), Embase (http://www.embase.com), and Google Scholar (https://scholar.google.com) were searched for English papers and two Iranian databases (MagIran [http://www. magiran.com] and SID [http://www.sid.ir]) for Persian papers from inception to March 2020. The selected keywords for databases included Needlestick OR Needlestick OR Sharp Injury OR needle* stick injuries* OR injur" OR needlestick injur* OR sharp* OR injur" AND Iran". Two researchers reviewed reports independently.

\section{Study selection and data extraction Inclusion and exclusion criteria}

Inclusion criteria The present study included only studies conducted in Iran and reported at least one factor affecting NSI.

Table 2 Results of heterogeneity among included studies

\begin{tabular}{|c|c|c|c|c|c|}
\hline Variables & \# of studies & $Q$ value & $I^{2}(\%)$ & $P$ value & Selected model \\
\hline Hepatitis B vaccination status (Incomplete vs. complete) & 4 & 9.9 & 69.9 & 0.019 & Random \\
\hline Employment status (Official vs. contract) & 5 & 9.4 & 57.7 & 0.041 & Random \\
\hline Education level (< 12 years vs. $>12$ years) & 16 & 73.5 & 79.5 & $<0.001$ & Random \\
\hline Marital status (Single vs. married) & 9 & 15.1 & 47.1 & 0.056 & Fixed \\
\hline Education level ( $<16$ years vs. $>16$ years) & 4 & 2.5 & 0.0 & 0.471 & Random \\
\hline Gender (females vs. males) & 27 & 111.7 & 76.7 & $<0.001$ & Random \\
\hline Attending in training course (No vs. yes) & 8 & 14.9 & 53.2 & 0.036 & Random \\
\hline Work experience $(<5$ years vs. $>5$ years $)$ & 5 & 10.8 & 63.2 & 0.028 & Random \\
\hline Job stress (severe vs. mild) & 3 & 7.8 & 74.3 & 0.020 & Random \\
\hline Work experience ( $<10$ yeas vs. $>10$ years) & 10 & 37.6 & 76.0 & $<0.001$ & Random \\
\hline Age $(<30$ vs. $>30)$ & 13 & 69.6 & 82.7 & $<0.001$ & Random \\
\hline Shift working (night vs. day) & 8 & 59.2 & 88.1 & $<0.001$ & Random \\
\hline Ward (surgical vs. medical) & 11 & 68.8 & 85.4 & $<0.001$ & Random \\
\hline Shift working (rotate vs. fixed) & 7 & 41.8 & 85.6 & $<0.001$ & Random \\
\hline Age (< 35 vs. $>35)$ & 4 & 1.5 & 0.0 & 0.679 & Fixed \\
\hline
\end{tabular}




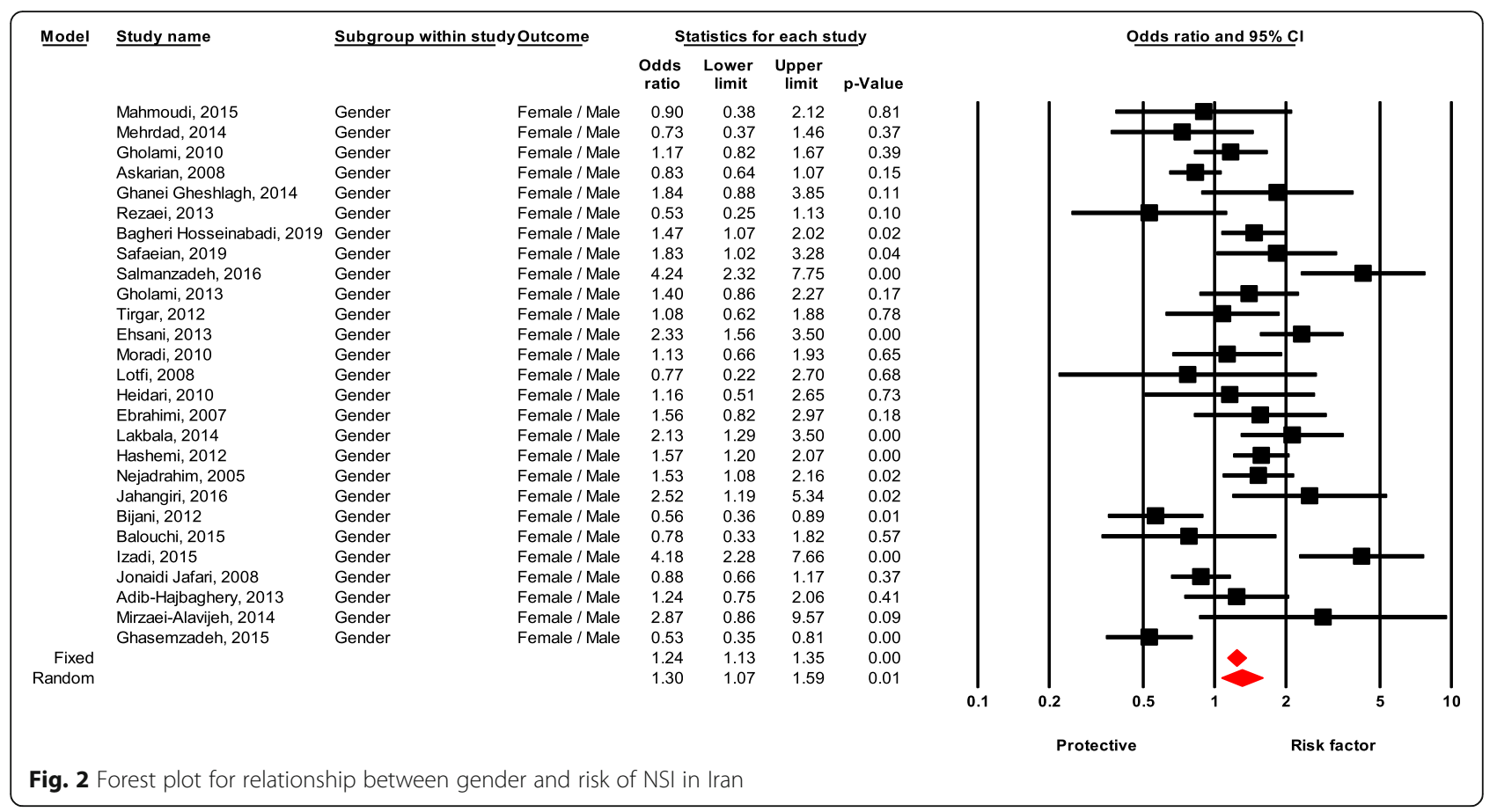

Exclusion criteria Studies without full text did not provide the information needed to enter the study and those that received a qualitative assessment score of less than 3.

\section{Definitions of some terms}

NSI: Needlestick injury for at least 12 months

Healthcare workers: A healthcare worker is one who delivers care and services to the sick and ailing either directly. The majority of people in this group are nurses.

Job stress: Job stress is a type of stress caused by conditions in the workplace affecting a person's performance. General Nordic questionnaire for psychological and social factors at work was used for assessing job stress.

\section{Quality assessment}

The Joanna Briggs Institute (JBI) Critical Appraisal Checklist was used for quality assessment of included studies. This checklist examines the quality of crosssectional studies. This checklist assesses 9 domains. The overall score above 7 indicates a high quality, between 4 and 6 shows medium quality, and below 3 shows poor quality.

\section{Screening of studies}

The initial search was conducted by two researchers (X and Y). Study screening, extraction of results, and quality assessment were performed independently by two researchers (A and B). If there was no agreement between

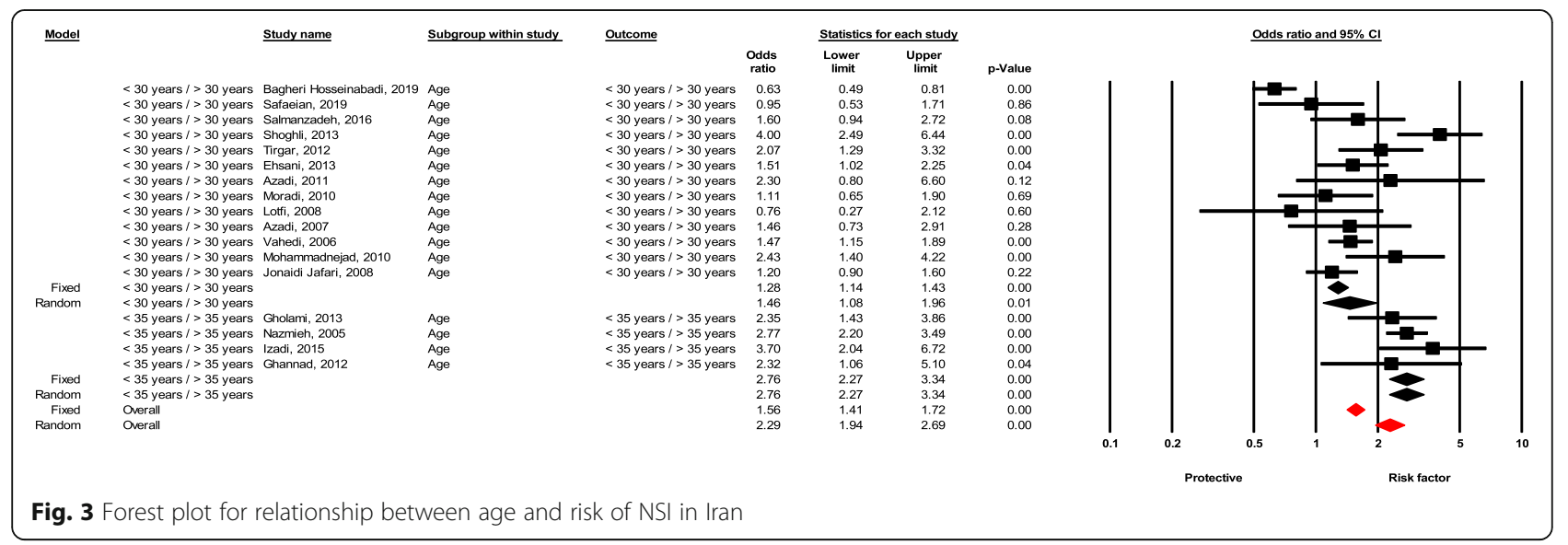




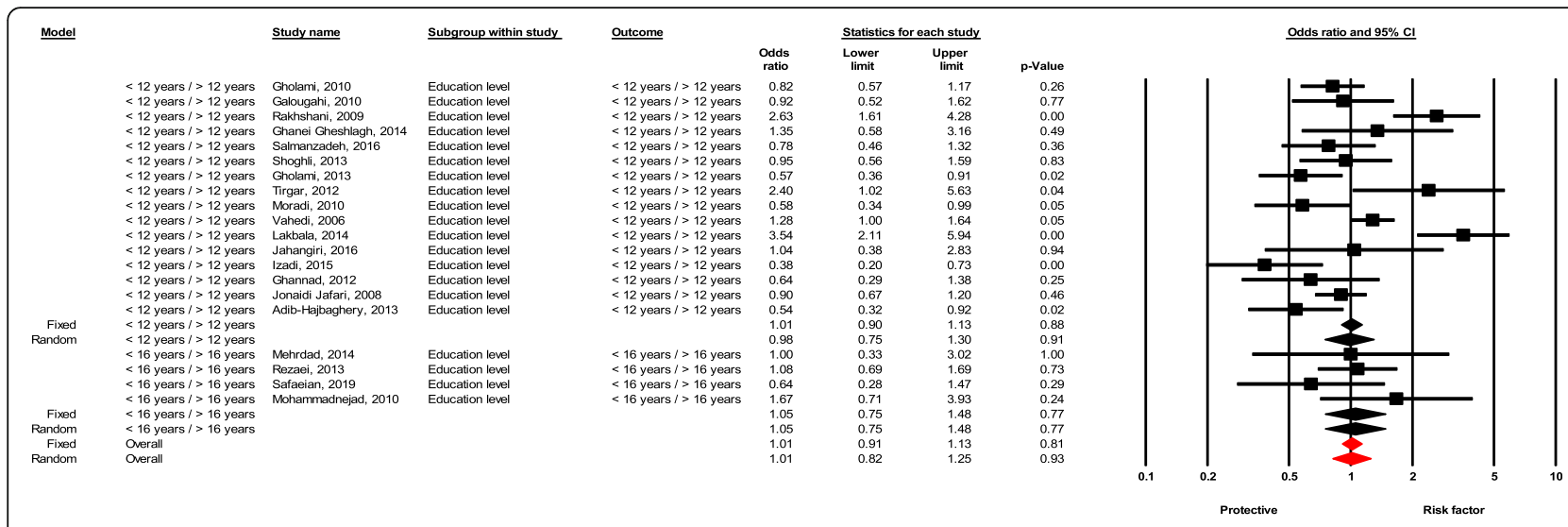

Fig. 4 Forest plot for relationship between education level and risk of NSI in Iran

the two researchers, the team leader (C) would announce the final opinion on that article.

\section{Statistical analysis}

The heterogeneity of the studies was investigated by Cochran's test (with a significance level of less than 0.1) and its combination using $I^{2}$ statistics (with a significance level greater than 50\%). In case of model heterogeneity, random effects were used by variance image method, and in case of non-heterogeneity, the fixed effects model was used. The odds ratio (OR) index was used to combine results from different studies. This index provided the ability to combine studies that reported results in different ways. All analyses were performed by CMA statistical software version 2 .

\section{Results}

Description of searched studies

A total of 312 reports were found initially. After removing duplicates, 251 reports remained for title and abstract review. In total, 59 studies met the inclusion criteria and entered into the second stage of evaluation. Eventually, 43 studies were included in the final analysis. It should be noted that the references to the published articles were also reviewed to add relevant studies. Reasons for exclusion were unrelated topic (191), unrelated study population [13], and repetitive results [4]. The flowchart of the studies are presented in Fig. 1.

\section{Description of the included studies}

Characteristics of the included studies [15, 21-64] are listed in Table 1.

\section{Results of quality assessment}

Eight studies were judged to have a high quality, and 35 had a medium quality.

\section{Results of heterogeneity}

Results of the study heterogeneity for each of the risk factors are shown in Table 2.

\section{Results of meta-analysis}

Results for NSI risk factors including gender, age, education level, employment status, job stress, and marital status are as follows:

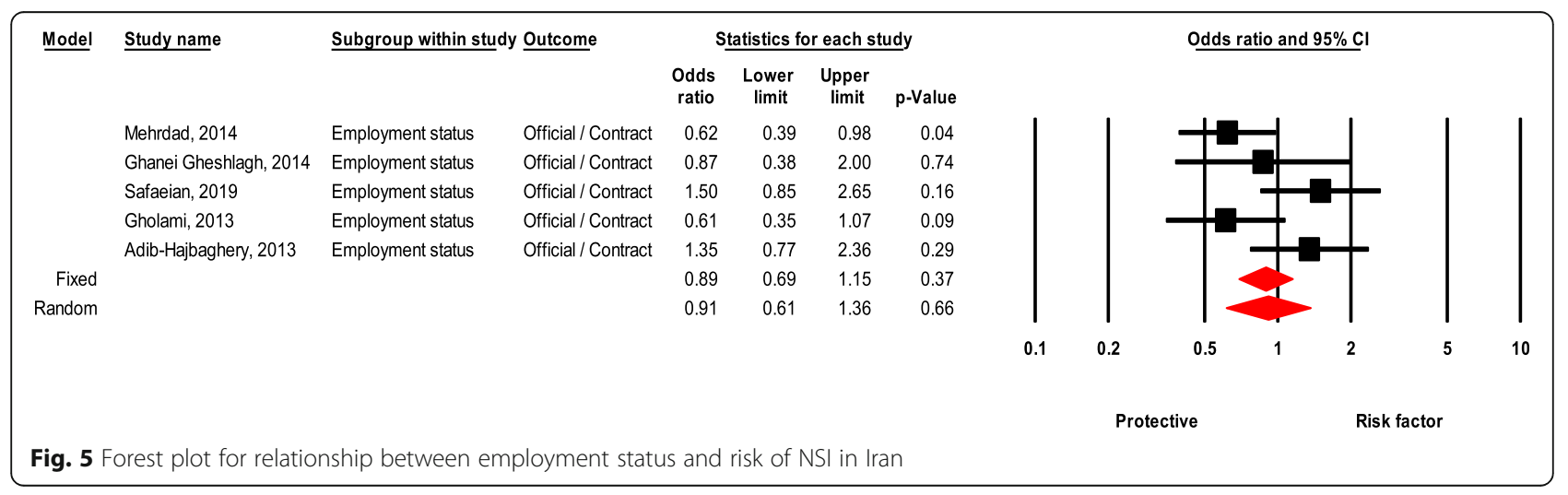




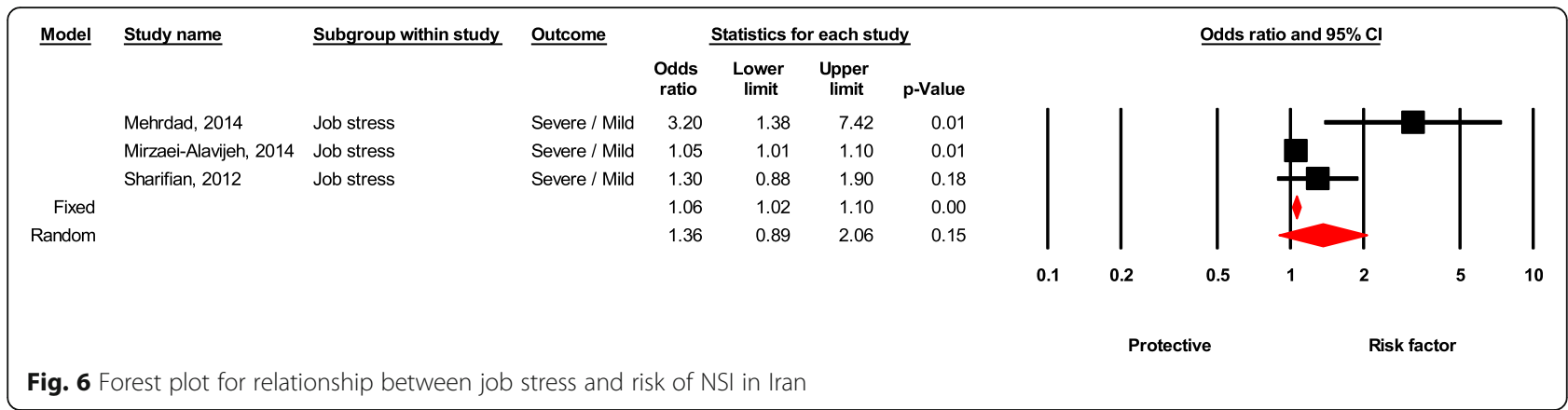

\section{Gender}

There was a significant difference between males and females experiencing NSI. Females had 30\% more NSI experience than males $(\mathrm{OR}=1.30,95 \% \mathrm{CI} 1.06-1.58, P$ value $=0.009)($ Fig. 2) .

\section{Age}

Healthcare workers under the age of 30 had significantly higher likelihood of experiencing NSI than those over the age of $30(\mathrm{OR}=1.45,95 \% \mathrm{CI} 1.07-$ $1.95, P$ value $=0.015)$, as well as healthcare workers under the age of 35 compared with those over the age of $35(\mathrm{OR}=2.75,95 \%$ CI $2.27-3.33, P$ value < 0.001) (Fig. 3).

\section{Education level}

There was no significant difference between healthcare workers in the NSI event based on the two levels of education of 12 years $(\mathrm{OR}=0.98,95 \% \mathrm{CI} 0.74-1.29, P$ value $=0.887)$ and 16 years $(\mathrm{OR}=1.05$, $95 \%$ CI $0.74-$ $1.48, P$ value $=0.781)($ Fig. 4$)$.

There was no significant difference for NSI in terms of education level $(\mathrm{OR}=0.98,95 \%$ CI 0.74-1.29, $P$ value $=0.887$; for 12 years education, and $\mathrm{OR}=1.05$, $95 \%$ CI $0.74-1.48, P$ value $=0.781$ for 18 years education) (Fig. 4).

\section{Employment status}

There was no significant difference for experiencing NSI between permanent healthcare workers with contractual workers $(\mathrm{OR}=0.91,95 \%$ CI $0.60-1.35, P$ value $=0.645)$ (Fig. 5).

\section{Job stress}

The healthcare workers with severe job stress were $36 \%$ more likely to experience NSI than those with moderate stress, although it was not statistically significant $(\mathrm{OR}=$ 1.36, 95 \% CI 0.89-2.08, $P$ value $=0.151$ ) (see Fig. 6).

\section{Marital status}

There was no significant difference between singles and married healthcare workers in the NSI event $(\mathrm{OR}=1.02$, $95 \%$ CI 0.86-1.21, $P$ value $=0.820)($ Fig. 7$)$.

\section{Shift working}

Workers with rotating shifts were significantly more likely to experience NSI compared to fixed time workers $(\mathrm{OR}=2.16$, $95 \%$ CI $1.47-3.15, P$ value $<0.001)$. Moreover, night-shift workers had higher likelihood of experiencing NSI compared with day-shift workers, but the difference was non-significant $(\mathrm{OR}=1.63,95 \% \mathrm{CI}$ 0.82-3.22, $P$ value $=0.161)$ (Fig. 8)

\begin{tabular}{|c|c|c|c|c|c|c|c|}
\hline \multirow[t]{11}{*}{ Model } & Study name & \multicolumn{2}{|c|}{ Subgroup within study Outcome } & \multicolumn{4}{|c|}{ Statistics for each study } \\
\hline & & & & $\begin{array}{l}\text { Odds } \\
\text { ratio }\end{array}$ & $\begin{array}{c}\text { Lower } \\
\text { limit }\end{array}$ & $\begin{array}{c}\text { Upper } \\
\text { limit }\end{array}$ & p-Valu \\
\hline & Mehrdad, 2014 & Maritial status & Single / Married & 1.03 & 0.64 & 1.65 & 0.90 \\
\hline & Rezaei, 2013 & Maritial status & Single / Married & 1.34 & 0.88 & 2.04 & 0.17 \\
\hline & Safaeian, 2019 & Maritial status & Single / Married & 1.04 & 0.58 & 1.87 & 0.9 \\
\hline & Tirgar, 2012 & Maritial status & Single / Married & 1.01 & 0.61 & 1.68 & 0.9 \\
\hline & Ehsani, 2013 & Maritial status & Single / Married & 0.66 & 0.45 & 0.99 & 0.04 \\
\hline & Mohammadnejad, 2010 & Maritial status & Single / Married & 2.11 & 1.21 & 3.67 & 0.0 \\
\hline & Heidari, 2010 & Maritial status & Single / Married & 1.22 & 0.53 & 2.80 & 0.63 \\
\hline & Izadi, 2015 & Maritial status & Single / Married & 0.69 & 0.41 & 1.16 & 0.16 \\
\hline & Adib-Hajbaghery, 2013 & Maritial status & Single / Married & 0.99 & 0.56 & 1.75 & 0.97 \\
\hline Fixed & & & & 1.02 & 0.86 & 1.21 & 0.82 \\
\hline andom & & & & 1.04 & 0.82 & 1.32 & 0.76 \\
\hline
\end{tabular}

Fig. 7 Forest plot for relationship between marital status and risk of NSI in Iran 


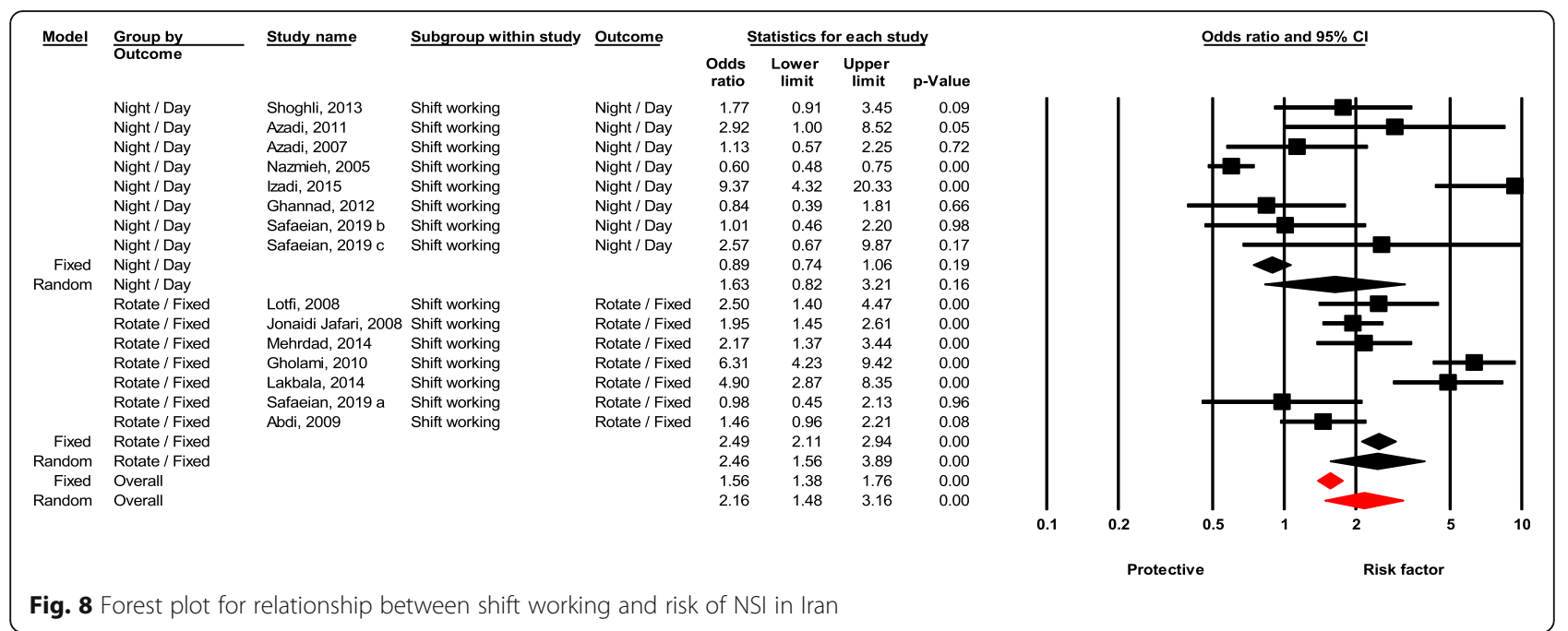

\section{Attending in training course}

Healthcare workers who did not attend the training courses were significantly $30 \%$ more likely to experience NSI than those who did the training $(\mathrm{OR}=1.30,95 \%$ CI 1.07-1.56, $P$ value $=0.006)($ Fig. 9) .

\section{Hepatitis B vaccination status}

Workers with incomplete vaccination against hepatitis $B$ were $23 \%$ less likely to experience NSI than those who were fully vaccinated, although non-significantly (OR = 0.77, 95 \% CI 0.41-1.41, P value = 0.400) (Fig. 10).

\section{Ward}

Healthcare workers in the surgery department were $83 \%$ more likely to have NSI than workers in the medical department, which was statistically significant $(\mathrm{OR}=1.83$, $95 \%$ CI 1.33-2.50, $P$ value < 0.001) (Fig. 11).

\section{Work experience}

Healthcare workers with less than 10 years of experience were $43 \%$ more likely to have NSI than workers with more than 10 years of experience, which was statistically significant $(\mathrm{OR}=1.43,95 \% \mathrm{CI} 1.04-1.95, P$ value $=$ 0.025). Moreover, healthcare workers with less than 5 years of experience had 35\% higher chance of NSI than those with more than 5 years of experience, although the difference was not significant $(\mathrm{OR}=1.35,95 \% \mathrm{CI}$ $0.90-2.02, P$ value $=0.146)($ Fig. 12$)$.

Summary of risk factors associated with NSI among HCW in Iran is presented in Fig. 13.

\section{Publication bias}

The results of the Egger $(P=0.737)$ and Begg test $(P=0.552)$ revealed no evidence of publication bias. The funnel plot for assessing publication bias is shown in Fig. 14.

\section{Discussion}

The aim of this systematic review and meta-analysis was to investigate the risk factors of NSI among healthcare workers in Iran. A number of risk factors associated with NSI have been identified. Factors such as female gender, younger age, work experience, job stress, work shift,

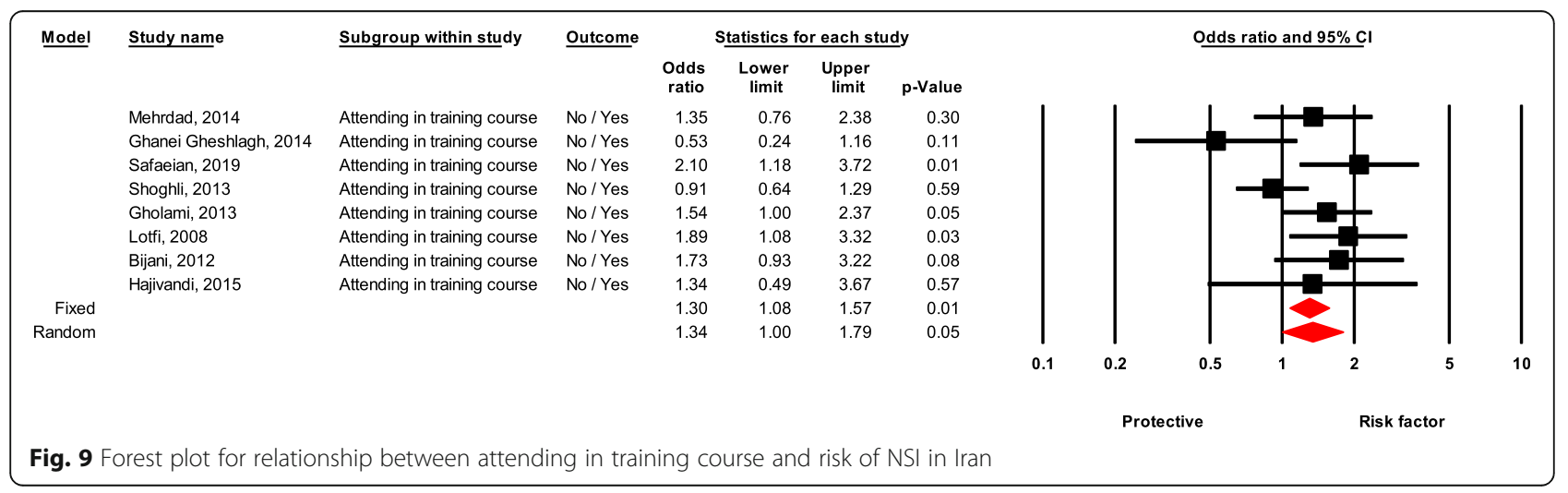




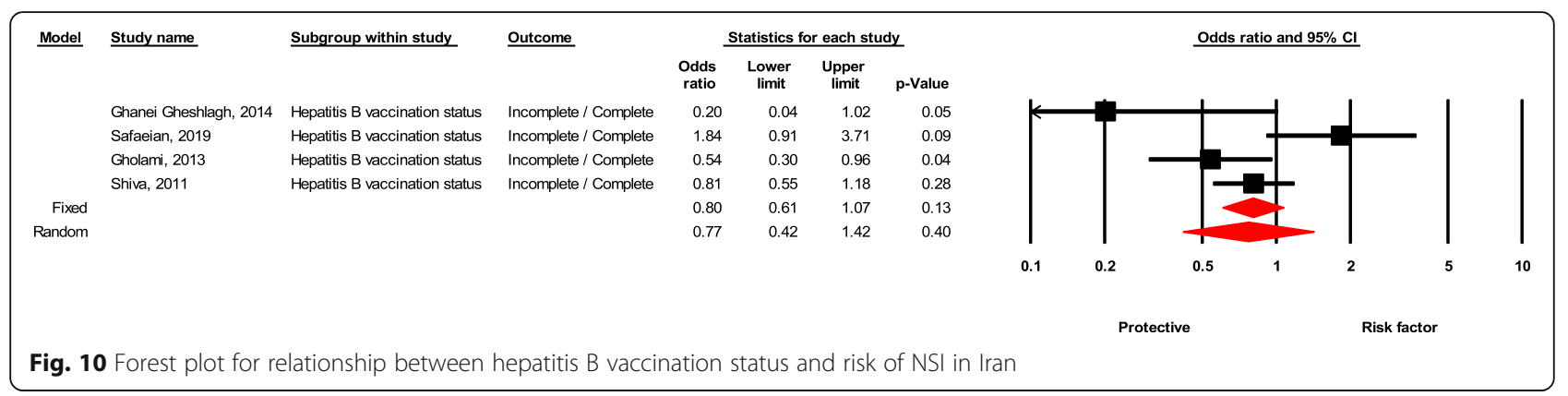

education, and hospital ward were found to have a significant influence on the incidence of NSI.

Females are about 30\% more likely to experience NSI injury than males. This might be due to various factors including stress and mental conflicts especially in the context of Iran as women have multiple roles in the home and workplace. Previous studies by Marawan Gabr et al., Teju Legesse et al., and Abimbola Oluwatosin et al. [65-67] are inconsistent since they identified males are more likely than females to experience NSI. It seems that the occurrence of NSI in terms of gender cannot be judged with confidence.

Furthermore, age and work experience of healthcare workers were identified as important factors related to NSI. Health workers under 30 years were more likely (about 50\%) to have NSI than workers over 30 years. In addition, workers with a work experience of less than 10 years were nearly twice as likely to be affected by NSI. Occupational accidents occur more among inexperienced HCWs than experienced counterparts. Reasons might include unfamiliarity with the work environment and work process, less training, less risk awareness, and lack of experience with the same accident (for her/himself or others). Similar reasons can be found in medical staff. The results of the present study showed that education is an effective factor, inexperienced and young staff receive less training than experienced staff. Tolesa Bekele et al. [68] found that HCWs under 30 years of age suffered from NSI almost twice as much as staff aged over 30 years. In a study by Marawan Gabr et al. [65], staff with less than 15 years of work experience were more likely to have NSI compared with staff with more work experience. In another study, Abimbola Oluwatosin et al. [67] found a significant association between age of staff and the incidence of NSI, where staff in the age group of 25 years and younger were more likely to have NSI than the age group of 46 and older. Similar findings have been reported in Rajput et al.'s study among nurses. Such studies also mentioned insufficient training and other factors mentioned above as the reason for more NSI in younger and less experienced staff.

Type of hospital ward showed a significant effect on the incident of NSI. Surgical ward posed a higher risk on the incident of NSI incident compared with other departments. In a similar vein, Marawan Gabr et al. [65] found the incidence of NSI in the surgical ward was significantly higher than the medical ward. Moreover, the most common injuries related to NSI occurred in the emergency department in two studies by Varun Goel

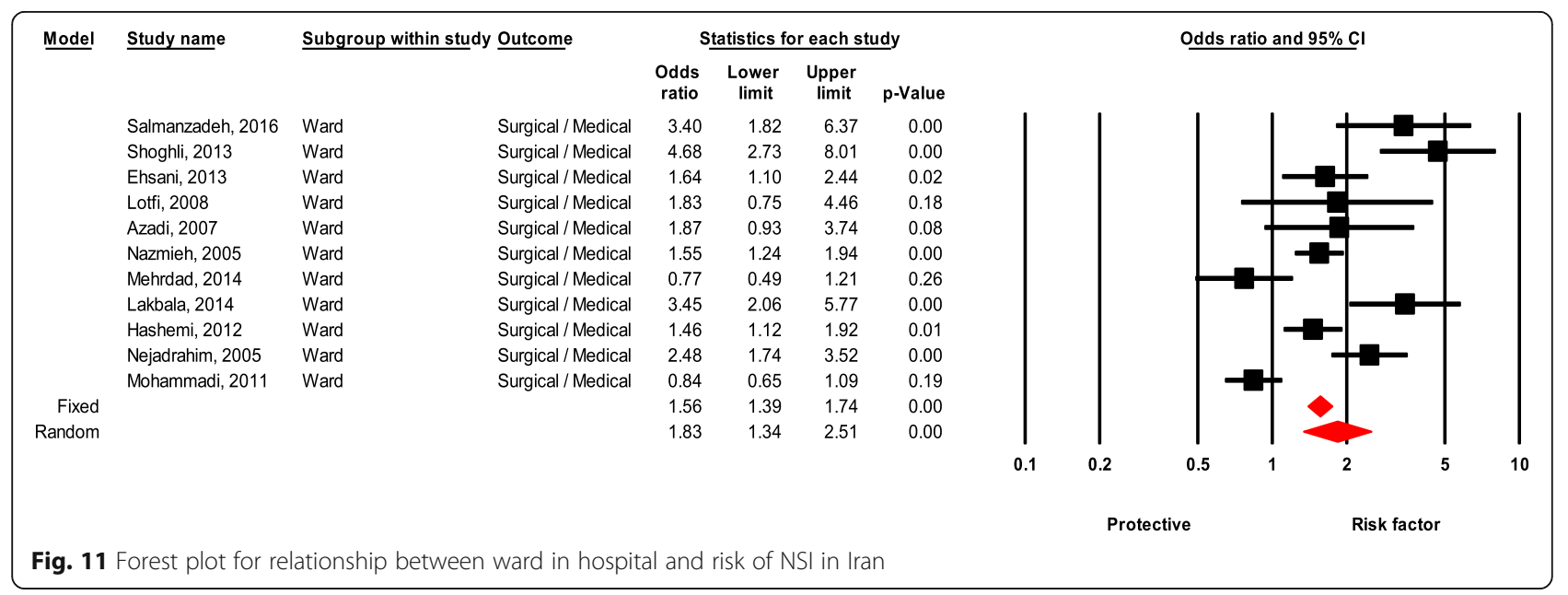



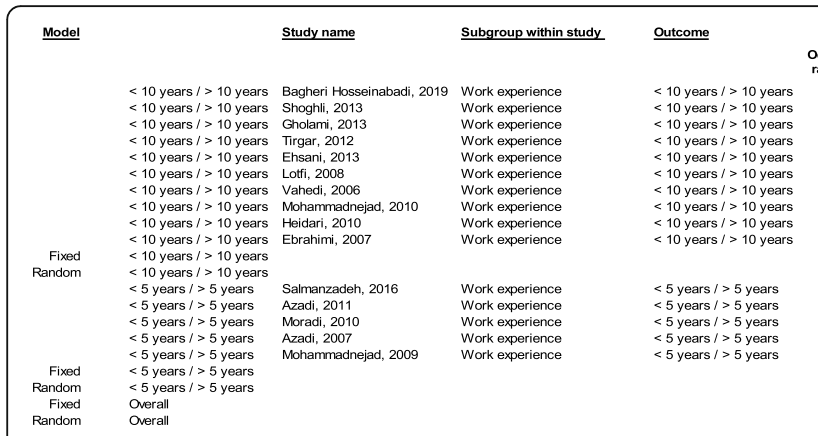

\begin{tabular}{|c|c|c|}
\hline \multirow[b]{2}{*}{$\begin{array}{l}\text { Odds } \\
\text { ratio }\end{array}$} & \multicolumn{2}{|c|}{ Statistics for each study } \\
\hline & $\begin{array}{c}\text { Lower } \\
\text { limit }\end{array}$ & $\begin{array}{l}\text { Upper } \\
\text { limit }\end{array}$ \\
\hline 0.51 & 0.33 & 0.78 \\
\hline 2.98 & 1.78 & 4.99 \\
\hline 1.40 & 0.88 & 2.23 \\
\hline $\begin{array}{l}2.22 \\
1.25\end{array}$ & $\begin{array}{l}1.41 \\
0.88\end{array}$ & $\begin{array}{l}3.50 \\
1.78\end{array}$ \\
\hline $\begin{array}{l}1.25 \\
1.22\end{array}$ & $\begin{array}{l}0.88 \\
0.50\end{array}$ & $\begin{array}{l}1.78 \\
2.96\end{array}$ \\
\hline 1.50 & 1.17 & $\begin{array}{l}2.96 \\
1.91\end{array}$ \\
\hline 2.01 & 1.06 & 3.81 \\
\hline 0.88 & 0.39 & 2.02 \\
\hline 1.84 & 0.98 & 3.46 \\
\hline $\begin{array}{l}1.41 \\
1.43\end{array}$ & $\begin{array}{l}1.23 \\
1.05\end{array}$ & $\begin{array}{l}1.62 \\
1.96\end{array}$ \\
\hline $\begin{array}{l}1.73 \\
0.76\end{array}$ & $\begin{array}{l}1.05 \\
0.45\end{array}$ & $\begin{array}{l}1.96 \\
1.29\end{array}$ \\
\hline 2.87 & 0.99 & 8.37 \\
\hline 1.07 & 1.03 & 1.12 \\
\hline 2.31 & 1.14 & 4.66 \\
\hline $\begin{array}{l}1.83 \\
1.07\end{array}$ & $\begin{array}{l}0.75 \\
1.03\end{array}$ & 4.49 \\
\hline 1.35 & $\begin{array}{l}1.03 \\
0.90\end{array}$ & $\begin{array}{l}1.12 \\
2.02\end{array}$ \\
\hline 1.10 & 1.05 & 1.14 \\
\hline 1.40 & 1.09 & 1.79 \\
\hline
\end{tabular}

$\begin{aligned} & \\ & \text { p-Value } \\ & 0.00 \\ & 0.00 \\ & 0.16 \\ & 0.00 \\ & 0.22 \\ & 0.66 \\ & 0.00 \\ & 0.03 \\ & 0.77 \\ & 0.06 \\ & 0.00 \\ & 0.02 \\ & 0.31 \\ & 0.05 \\ & 0.00 \\ & 0.02 \\ & 0.18 \\ & 0.00 \\ & 0.15 \\ & 0.00 \\ & 0.01\end{aligned}$

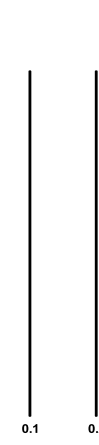

Odds ratio and $95 \% \mathrm{Cl}$

Fig. 12 Forest plot for relationship between Work experience and risk of NSI in Iran

et al. [7] and Tolesa Bekele et al. [68]. The high incidence of NSIs in the surgery and emergency wards might be caused by high levels of stress resulting from exposure to high-risk patients, work sensitivity, and the need for extreme attention to patients which in turn reduces the nurses' focus during work and increases NSI likelihood.

Information about the type of healthcare profession in our study was limited. In Gańczak et al.'s study, being a doctor was associated with greater odds $(\mathrm{OR}=4.2)$ of suffering from injures in surgical wards versus nurses [69]. A systematic review and meta-analysis by Bouya et al. [70] about job category and NSIs show that prevalence of NSIs was highest among dentists (59.1\%). The prevalence of NSIs in other occupational groups was $42.8 \%$ for nurses, $46.4 \%$ for physicians, and $45.3 \%$ for nursing students [70]. On the other hand, in some studies, nurses are considered to have high risk of NSIs compared with other groups [71, 72].

The present review found that Job stress is likely to increase NSI incident. Although no significant difference was found between severe and moderate job stress, staff with higher levels of stress had 36\% more chance to experience NSI. In a study by Dilie et al., they showed that almost half of the staff with job stress experienced NSI [73]. Job stress can affect workers' physical, physiological, and psychological responses and, in turn, their mental, physical, or emotional activities leading to more

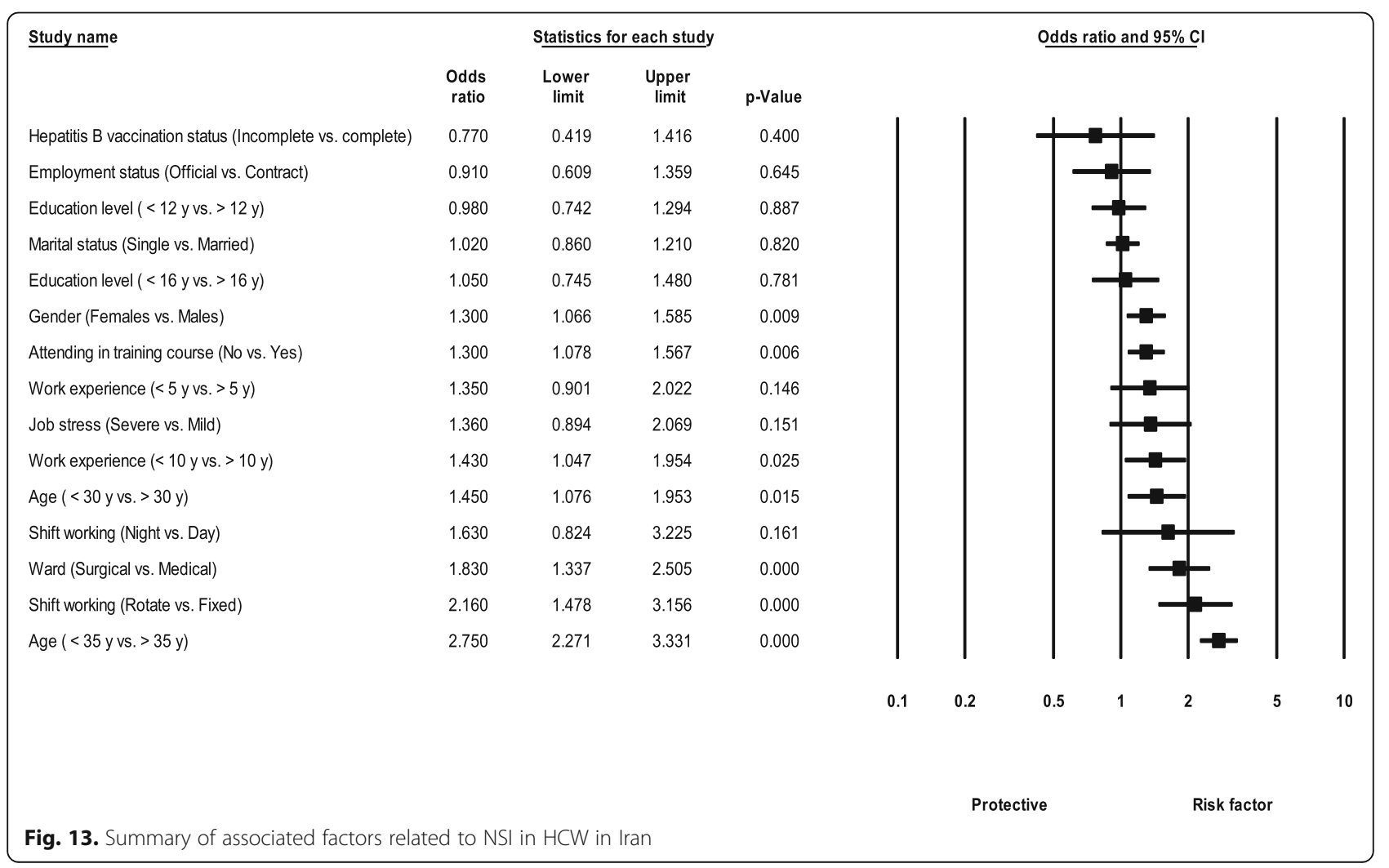




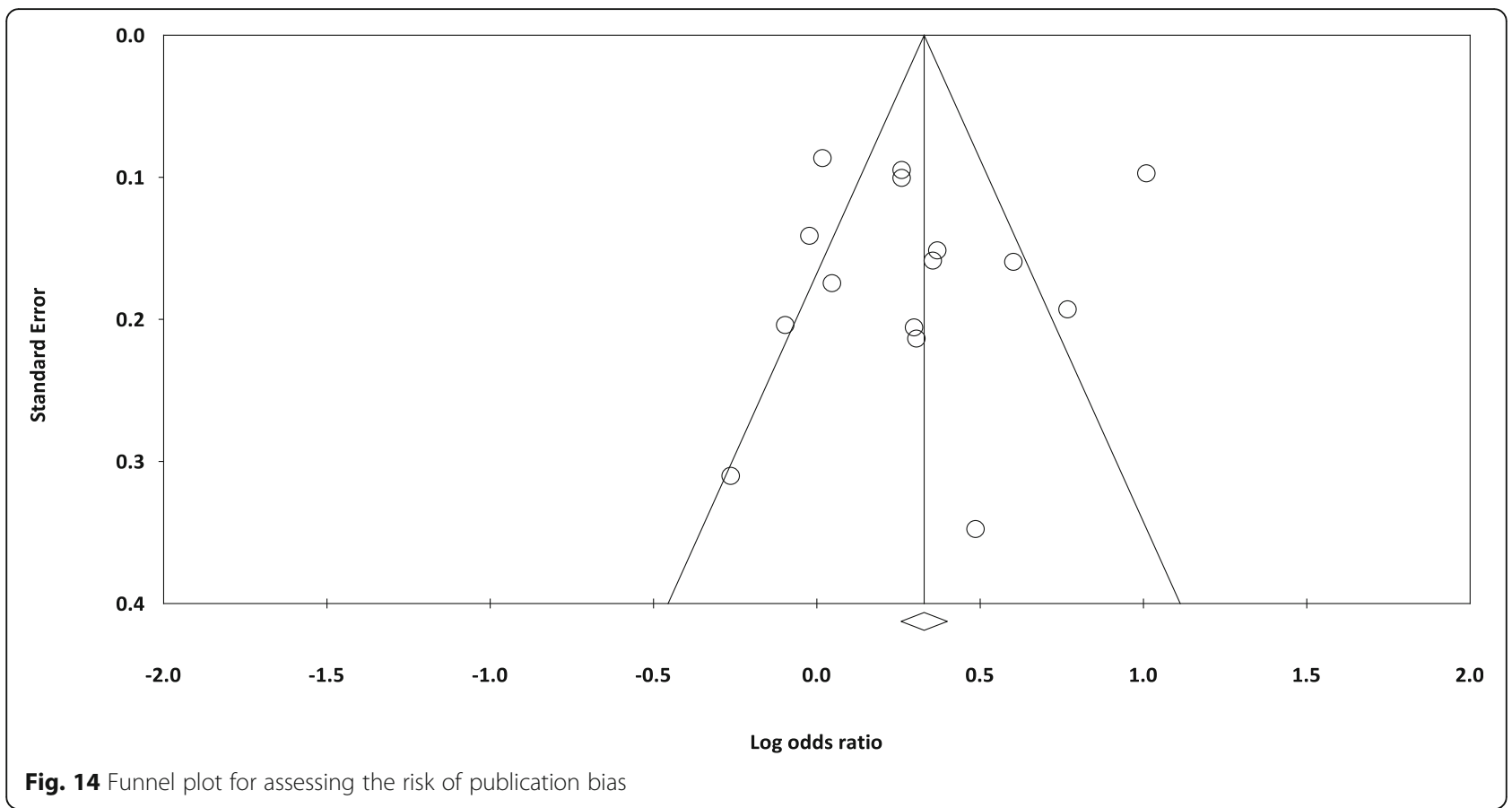

mistakes during work and reduced work performance [74]. Consequently, NSIs are quite likely among staff with higher job stress.

The present review showed that staff with rotational and night shifts are more likely to have NSI than others. Similar to the present findings, Marawan Gabr et al. showed that night shifts increase NSI likelihood. They found that staff with more than 2 night shifts per month were more likely to experience NSI [65]. One possible explanation could be the changes in body's natural physiological cycle as it is related to stress and NSIs. However, in a non-aligned study, Kasatpibal et al. found that most NSIs for nurses in the surgery rooms occurred during morning shifts. This is also justified by the high workload of nurses (e.g., surgeries) in the morning shift [75]. Therefore, it seems that the incident of NSIs might depend on the workplace situation and job type.

Training courses were also identified as one of the key factors affecting the occurrence of NSIs. The incidence of NSIs was shown to be approximately one third (30\%) in those who took training courses. In a study by Kasatpibal et al. [75], the effect of training with and without practicing on the incidence of NSIs was assessed. Staff who had training without practicing were significantly (about 53\%) more likely to experience NSI. In another study evaluating the effect of attendance in training sessions, staff who did not attend the training sessions suffered more NSIs than staff who attended training [65]. On-job training can play a crucial role in increasing their performance and reducing job risks due to being in a clinical environment and direct exposure to risk factors.
For this reason, in various studies, trained staff were less likely to face occupational hazards and injuries. These cases show a direct impact of clinical education on staff's performance and NSI incident.

\section{Strengths and limitations}

Previous meta-analyses conducted in Iran have estimated the prevalence of NSIs. However, the present study aimed to estimate the risk factors of NSI. Two limitations of this review were the lack of detailed information about the type of healthcare professions and the content of training packages.

\section{Recommendations}

It is recommended that healthcare authorities plan regular training programs for the prevention of NSIs in healthcare workers. In order to improve these training methods, staff evaluation should be done in different time periods, and possible mistakes should be corrected. Other recommendations are to establish uniform policies across all hospitals about the management of NSIs and performing periodic practical and verbal exams on personnel knowledge, attitude, and performance regarding prevention of NSIs.

\section{Conclusions}

In conclusion, this review identified key risk factors including young age, less work experience, work shift, and female gender for NSIs in Iran. Preventive activities based on known risk factors can reduce the burden of NSI on healthcare personnel. 


\section{Abbreviations}

HCW: Health-care workers; NSI: Needlestick injuries

\section{Acknowledgements}

The authors wish to thank Dr. Reza Daryabeygi at the Deakin University, Melbourne, Australia for his invaluable assistance in English editing this manuscript.

\section{Availability of supporting data}

All relevant data are within the manuscript and its supporting information files.

\section{Authors' contributions}

GP and SH: concept development (provided idea for the research). SH, MJ, GP, and MS: design (planned the methods to generate the results). GP and SH: supervision (provided oversight, responsible for organization and implementation, writing of the manuscript). HR, MM, and RT: data collection/ processing (responsible for experiments, patient management, organization or reporting data). MS, MF and SH: analysis/interpretation (responsible for statistical analysis, evaluation, and presentation of the results). SH and MF: literature search (performed the literature search). All authors: writing (responsible for writing a substantive part of the manuscript)

\section{Funding}

None

\section{Declarations}

\section{Ethics approval and consent to participate}

Not applicable

\section{Consent for publication}

Not applicable

\section{Competing interests}

The authors declare that they have no competing interests.

\section{Author details}

${ }^{1}$ Faculty of Health, Baqiyatallah University of Medical Sciences, Tehran, Iran. ${ }^{2}$ Health Research Center, Life Style Institute, Baqiyatallah University of Medical Sciences, Tehran, Iran. ${ }^{3}$ Nursing and Midwifery Care Research Center, Mashhad University of Medical Sciences, Mashhad, Iran. ${ }^{4}$ Department of Occupational Health and Safety, School of Public health and safety, Shahid Beheshti University of Medical Sciences, Tehran, Iran. ${ }^{5}$ Department of Occupational Health Engineering, School of Public Health, Shahid Beheshti University of Medical Sciences, Tehran, Iran. ${ }^{6}$ Occupational Health Engineering, Department of Occupational Health Engineering, School of Public Health, Kashan University of Medical Sciences, Kashan, Iran.

\section{Received: 10 November 2020 Accepted: 17 March 2021} Published online: 01 April 2021

\section{References}

1. Himmelreich H, Rabenau HF, Rindermann M, Stephan C, Bickel M, Marzi I, et al. The management of needlestick injuries. Dtsch Arztebl Int. 2013;110(5): 61-7. https://doi.org/10.3238/arztebl.2013.0061

2. Beltrami EM, Williams IT, Shapiro CN, Chamberland ME. Risk and management of blood-borne infections in health care workers. Clin Microbiol Rev. 2000;13(3):385-407. https://doi.org/10.1128/CMR.13.3.385.

3. Marusic V, Markovic-Denic L, Djuric O, Protic D, Dubljanin-Raspopovic E. Knowledge about blood-borne pathogens and the prevalence of needle stick injuries among medical students in Serbia. Zdr Varst. 2017;56(3):179-84. https://doi.org/10.1515/sjph-2017-0024.

4. Tarantola A, Abiteboul D, Rachline A. Infection risks following accidental exposure to blood or body fluids in health care workers: a review of pathogens transmitted in published cases. Am J Infect Control. 2006;34(6): 367-75. https://doi.org/10.1016/j.ajic.2004.11.011.

5. Coppola N, De Pascalis S, Onorato L, Calò F, Sagnelli C, Sagnelli E. Hepatitis $B$ virus and hepatitis $C$ virus infection in healthcare workers. World J Hepatol. 2016;8(5):273-81. https://doi.org/10.4254/wjh.v8.15.273.
6. Joukar F, Mansour-Ghanaei F, Naghipour MR, Hassanipour S. Knowledge, distribution and risk factors of hepatitis $B$ and $C$ infection in high-risk groups in Guilan Province. Iran. Hepat Mon. 2018;18(8):e65870.

7. Goel V, Kumar D, Lingaiah R, Singh S. Occurrence of needlestick and injuries among health-care workers of a tertiary care teaching hospital in North India. J Lab Physicians. 2017;9(1):20-5. https://doi.org/10.4103/0974-2727.1 87917.

8. Pavithran VK, Murali R, Krishna M, Shamala A, Yalamalli M, Kumar AV. Knowledge, attitude, and practice of needle stick and sharps injuries among dental professionals of Bangalore, India. J Int Soc Prev Community Dent 2015;5(5):406-12. https://doi.org/10.4103/2231-0762.165932.

9. Kunishima $\mathrm{H}$, Yoshida $\mathrm{E}$, Caputo J, Mikamo H. Estimating the national cost burden of in-hospital needlestick injuries among healthcare workers in Japan. PLoS One. 2019;14(11):e0224142.

10. Garus-Pakowska A, Górajski M. Epidemiology of needlestick and sharp injuries among health care workers based on records from 252 hospitals for the period 2010-2014, Poland. BMC Public Health. 2019;19(1):634.

11. Ghanei Gheshlagh R, Aslani M, Shabani F, Dalvand S, Parizad N. Prevalence of needlestick and sharps injuries in the healthcare workers of Iranian hospitals: an updated meta-analysis. Environ Health Preventive Med. 2018; 23(1):44.

12. Saadeh R, Khairallah K, Abozeid H, Al Rashdan L, Alfaqih M, Alkhatatbeh O. Needle stick and sharp injuries among healthcare workers: a retrospective six-year study. Sultan Qaboos Univ Med J. 2020;20(1):e54-62. https://doi. org/10.18295/squmj.2020.20.01.008.

13. Singru SA, Banerjee A. Occupational exposure to blood and body fluids among health care workers in a teaching hospital in mumbai, India. Indian J Commun Med. 2008;33(1):26-30.

14. Floreani A, Baldo V, Cristofoletti M, Renzulli G, Valeri A, Zanetti C, et al. Longterm persistence of anti-HBs after vaccination against $\mathrm{HBV}$ : an 18 year experience in health care workers. Vaccine. 2004;22(5-6):607-10. https://doi. org/10.1016/j.vaccine.2003.09.001.

15. Jahangiri M, Rostamabadi A, Hoboubi N, Tadayon N, Soleimani A. Needle stick injuries and their related safety measures among nurses in a university hospital, Shiraz, Iran. Saf Health Work. 2016;7(1):72-7. https://doi.org/10.101 6/.j.shaw.2015.07.006.

16. Nasiri A, Balouchi A, Rezaie-Keikhaie K, Bouya S, Sheyback M, Rawajfah OA. Knowledge, attitude, practice, and clinical recommendation toward infection control and prevention standards among nurses: A systematic review. Am J Infect Control. 2019;47(7):827-33. https://doi.org/10.1016/j.ajic.2 018.11.022.

17. Sahiledengle B, Tekalegn Y, Woldeyohannes D, Quisido BJE. Occupational exposures to blood and body fluids among healthcare workers in Ethiopia: a systematic review and meta-analysis. Environ Health Prev Med. 2020;25(1):58.

18. Motaarefi H, Mahmoudi H, Mohammadi E, Hasanpour-Dehkordi A. Factors associated with needlestick injuries in health care occupations: a systematic review. Journal of clinical and diagnostic research : JCDR. 2016;10(8):IE01IE4. https://doi.org/10.7860/JCDR/2016/17973.8221.

19. Rezaei S, Hajizadeh M, Zandian H, Fathi A, Nouri B. Period prevalence and reporting rate of needlestick injuries to nurses in Iran: a systematic review and meta-analysis. Research in nursing \& health. 2017;40(4):311-22. https:// doi.org/10.1002/nur.21801.

20. Sayehmiri K, Mohammadi E, Mohammadi I, Sayehmiri F. Epidemiology of needle sticks and sharps injuries in healthcare workers in Iran: a systematic review and meta-analysis. Iran Occupational Health. 2014;11(5):93-103.

21. Abdi M, Najafipour S, Hamidizade S, Jamali F, Pournoroz N, et al. jumsjmj. 2009:7(3):30-8.

22. Adib-Hajbaghery M, Lotfi MS. Behavior of healthcare workers after injuries from sharp instruments. Trauma monthly. 2013;18(2):75-80. https://doi.org/1 0.5812/traumamon.12779.

23. Askarian $M$, Malekmakan $L$. The prevalence of needle stick injuries in medical, dental, nursing and midwifery students at the university teaching hospitals of Shiraz, Iran. Indian journal of medical sciences. 2006;60(6):22732. https://doi.org/10.4103/0019-5359.25904.

24. Askarian M, Shaghaghian S, Gillen M, Assadian O. Body fluid exposure in nurses of Fars Province, southern Iran. Arch Iranian Med. 2008;11(5):515-21.

25. Askarian M, Shaghaghian S, McLaws ML. Needlestick injuries among nurses of Fars province, Iran. Annals of epidemiology. 2007;17(12):988-92. https:// doi.org/10.1016/j.annepidem.2007.07.106.

26. Azadi A, Anoosheh M. Needlestick injuries reporting among clinical nurses. IJN. 2007;20(49):7-14. 
27. Azadi A, Anoosheh M, Delpisheh A. Frequency and barriers of underreported needlestick injuries amongst Iranian nurses, a questionnaire survey. J Clin Nurs. 2011;20(3-4):488-93. https://doi.org/10.1111/j.1365-2702.2 010.03252.x.

28. Bagheri Hosseinabadi M, Khanjani N, Etemadinezhad S, Samaei SE, Raadabadi M, Mostafaee M. The associations of workload, individual and organisational factors on nurses' occupational injuries. J Clin Nurs. 2019; 28(5-6):902-11. https://doi.org/10.1111/jocn.14699.

29. Balouchi A, Shahdadi H, Ahmadidarrehsima S, Rafiemanesh H. The frequency, causes and prevention of needlestick injuries in nurses of Kerman: a cross-sectional study. J Clin Diagnostic Res. 2015;9(12):Dc13-5.

30. Bijani B, Azimiyan J. Epidemiology and risk factors of needle stick injuries among nurses in Bou-Ali Sina teaching hospital, Qazvin. J shahid beheshti nursing and midwifery. 2012;22(78):1-8.

31. Bijani B, Sotudehmanesh S, Mohammadi N. Epidemiological features of needle stick injuries among nursing staff; 2011

32. Ebrahimi H, Khosravi A. Needlestick injuries among nurses. J Res Health Sci. 2007;7(2):56-62.

33. Ehsani SR, Mohammadnejad E, Hadizadeh MR, Mozaffari J, Ranjbaran S, Deljo $R$, et al. Epidemiology of needle sticks and sharp injuries among nurses in an Iranian teaching hospital. Arch Clin Infect Dis. 2012;8(1):27-30. https://doi.org/10.5812/archcid.14409.

34. Galougahi MH. Evaluation of needle stick injuries among nurses of Khanevadeh Hospital in Tehran. Iranian J Nurs Midwifery Res. 2010;15(4): 172-7.

35. Ghanei Gheshlagh R, Zahednezhad H, Shabani F, Hameh M, Ghahramani M, Farajzadeh $M$, et al. Needle sticks injuries and its related factors among nurses. Iran J Nursing. 2014;27(89):21-9.

36. Ghannad MS, Majzoobi MM, Ghavimi M, Mirzaei M. Needlestick and sharp object injuries among health care workers in Hamadan Province, Iran. J Emerg Nurs. 2012;38(2):171-5; quiz 202. https://doi.org/10.1016/j.jen.2011.01. 009.

37. Ghasemzadeh I, Kazerooni M, Davoodian P, Hamedi Y, Sadeghi P. Sharp injuries among medical students. Global J Health Sci. 2015;7(5):320-5.

38. Gholami A, Borji A, Lotfabadi P, Asghari A. Risk factors of needlestick and sharps injuries among healthcare workers. Int J Hospital Res. 2013;2(1):31-8.

39. Gholami A, Salarilak S, Alinia T, Nejad RR. Study of needle stick injuries among health care workers at teaching hospitals in Urmia. Iranian J Epidemiol. 2010;6(3):57-61.

40. Hajivandi A, Ahmadi B, Rezaeeshiri A, Ramavandi B. A survey on the sharp and cutting wastes injury in nurses of the Bushehr city hospitals in the year 1392. J Urmia Nurs Midwifery Faculty. 2015;13(6):490-7.

41. Hashemi SH, Torabian S, Mamani M, Moazen DS. The prevalence of needlestick and sharps injuries among health care workers in Hamadan, Iran. UMSHA. 2012;18(4):41-6.

42. Heidari M, Shahbazi S. Prevalence of needle sticks exposure in operation room's staff of Borujen \& Lordegan hospitals - 2010-2011. Commun Health J. 2010;5(1):32-7.

43. Mohammadnejad I, Esfandbad M. Injuries of sinking sharp objects and the rate of reporting in emergency nurses of Tehran University of Medical Sciences. Iranian J Infect Dis Tropical Med. 2010;15(48):49-54.

44. Mohammadnejad I, Esfandbad M, Ehsani SR, Deljoo R. Epidemiological aspects of occupational exposure to sharp and winning objects in nurses. Iranian J Infect Dis Tropical Med. 2009;14(45):47-50.

45. Izadi N, Chavoshi F, Sadeghi M. Needlestick and sharps injuries among the personnel of Baharlou Hospital in Tehran, Iran. Jundishapur J Health Sci. 2015;7(4):e30649.

46. Lakbala P, Sobhani G, Lakbala M, Inaloo KD, Mahmoodi H. Sharps injuries in the operating room. Environmental health and preventive medicine. 2014; 19(5):348-53. https://doi.org/10.1007/s12199-014-0401-y.

47. Lotfi R, Gashtasbi A. Needle stick and sharps injuries and its risk factors among health center personnel (Astara, Iran, 2006). Babol-Jbums. 2008;10(4): 71-7.

48. Mahmoudi N, Sepandi M, Mohammadi AS, Masoumbeigi H. Epidemiological aspects of needle stick injuries among nurses in a military hospital. Work 2015;12(5.64):9 41-4.99.

49. Mehrdad R, Atkins EH, Sharifian SA, Pouryaghoub G. Psychosocial factors at work and blood-borne exposure among nurses. Int J Occupational Environmental Med. 2014;5(1):32-9.

50. Mirzaei-Alavijeh M, Jalilian F, Karami-Matin B, Ghaderi A, Mahboubi M, Janizadeh $\mathrm{R}$, et al. Needle-stick and medication errors in emergency nurses are due to their job stresses? A descriptive study in Kermanshah Hospitals, Iran. J Biol Today's World. 2014;3:185-8.

51. Mohammadi N, Allami A, Mohamadi RM. Percutaneous exposure incidents in nurses: knowledge, practice and exposure to hepatitis b infection. Hepatitis Monthly. 2011;11(3):186-90.

52. Moradi A, Mostafavi E, Moradi A. The prevalence and causes of needle stick injuries among the primary health care workers of Bahar city, Hamadan Province. Iran Occupational Health. 2010;7(2):39-42.

53. NA JJ, Shasti M, Izadi M, Ranjbar R, Ghasemi M. Evaluation of frequency of exposure to medical sharp devices among nurses of a university hospital. J Mil Med. 2008;10(2):119-28.

54. Nazmieh H, Najaf-Yarandi A, Janmohammadi S, Hosseini F. Assessment of the injuries caused by sharp instruments in the health workers of university hospitals, in Yazd. IJN. 2005:18(43):49-59.

55. Nejadrahim R, Gharahughi N, Sistanizade M. Needlestick Injuries in the Health Care Workers of Urmia Educational Hospitals. UNMF. 2005:3(2):0.

56. Rakhshani F, Heidari M, Barati S. Prevalence of needlestick injuries among the healthcare professionals in Zahedan Medical Sciences University. Iranian J Epidemiol. 2009;4(3):87-91.

57. Rezaei S, Rabi Rad N, Tamizi Z, Fallahi Khoshknab M, Mohamad NE. An Investigation into occupational hazards faced by nurses in paediatrics hospitals of Tehran University of Medical Sciences, 2006-2009. Int J Community Based Nurs Midwifery. 2013;1(4):200-7.

58. Safaeian A, Tavakolifard N, Zand S. Risk factors assessment of needle-stick injury among the healthcare workers of Alzahra Hospital, Isfahan, Iran. J Isfahan Med School. 2019;36(506):1463-71.

59. Salmanzadeh S, Rahimi Z, Goshtasbipour M, Meripoor M. The prevalence of needle-stick injuries among healthcare workers in Dasht-e-Azadegan, Southern West of Iran. Int J Pharmaceutical Res Allied Sci. 2016;5(2):417-22.

60. Sharifian A, Aminian O, Afshari SL. Occupational stress and its relationship with needle stick injury among emergency department personnel. Occup Med Quarterly J. 2012;3(4):7-13.

61. Shiva F, Sanaei A, Shamshiri AR, Ghotbi F. Survey of needle-stick injuries in paediatric health personnel of 5 university hospitals in Tehran. JPMA The Journal of the Pakistan Medical Association. 2011;61(2):127-31.

62. Shoghli A, Mousavi Nasab N, Ghorchian F, Masoumi H, Momtazi S. Study of theneedle sticks injury (NSI) among the Zanjan educational hospitals staff. J Adv Med Biomed Res. 2013;21(85):131-41.

63. Tirgar A, F G. A survey on needlestick injuries and related occupational factors among the Nurses. JHSW. 2012;1(2):31-8.

64. Vahedi MS, Ahsan B, Ardalan M, Shahsavari S. Prevalence and causes of needle stick injuries, in medical personnels of Kurdistan University's hospitals and dealing with such injuries due to contaminated sharp tools in 1383. HBI_Journals. 2006;11(2):43-50.

65. Gabr HM, El-Badry AS, Younis FE. Risk factors associated with needlestick injuries among health care workers in Menoufia Governorate, Egypt. The international journal of occupational and environmental medicine. 2018;9(2): 63-8. https://doi.org/10.15171/ijoem.2018.1156.

66. Legesse W, Anemaw W, Mekonen T, Nigus D. Prevalence of needle sticks injury and its associated factors among health care workers in Bahir Dar city health centers, Northwest Ethiopia. Int J Infect Control. 2015;11(2):1-7.

67. Oluwatosin OA, Oladapo MM, Asuzu MC. Needlestick injuries among health care workers in Ondo State, Nigeria. Int J Med Public Health. 2016;6(1):31-4.

68. Bekele T, Gebremariam A, Kaso M, Ahmed K. Factors associated with occupational needle stick and sharps injuries among hospital healthcare workers in Bale Zone. Southeast Ethiopia. PLoS One. 2015;10(10):e0140382. https://doi.org/10.1371/journal.pone.0140382.

69. Gańczak M, Bohatyrewicz A, Korzeń M, Karakiewicz B. The comparison of sharps injuries reported by doctors versus nurses from surgical wards in the context of the prevalence of HBV, HCV and HIV infections. Polski przeglad chirurgiczny. 2012;84(4):190-5. https://doi.org/10.2478/v10035-012-0031-2.

70. Bouya S, Balouchi A, Rafiemanesh H, Amirshahi M, Dastres M, Moghadam $M P$, et al. Global prevalence and device related causes of needle stick injuries among health care workers: a systematic review and meta-analysis. Ann Global Health. 2020:86(1):35.

71. Safety $\mathrm{O}$, Administration $\mathrm{H}$. Facts about hospital worker safety. Washington, DC: OSHA; 2013

72. Elseviers MM, Arias-Guillén M, Gorke A, Arens HJ. Sharps injuries amongst healthcare workers: review of incidence, transmissions and costs. Journal of renal care. 2014;40(3):150-6. https://doi.org/10.1111/jorc.12050.

73. Dilie A, Amare D, Gualu T. Occupational exposure to needle stick and sharp injuries and associated factors among health care workers in Awi Zone, 
Amhara Regional State, Northwest Ethiopia, 2016. Journal of Environmental and Public Health. 2017;2017:1-6. https://doi.org/10.1155/2017/2438713.

74. Butts MM, Vandenberg RJ, DeJoy DM, Schaffer BS, Wilson MG. Individual reactions to high involvement work processes: investigating the role of empowerment and perceived organizational support. J Occup Health Psychol. 2009;14(2):122-36. https://doi.org/10.1037/a0014114.

75. Kasatpibal N, Whitney JD, Katechanok S, Ngamsakulrat S, Malairungsakul B, Sirikulsathean $\mathrm{P}$, et al. Prevalence and risk factors of needlestick injuries, sharps injuries, and blood and body fluid exposures among operating room nurses in Thailand. Am J Infect Control. 2016;44(1):85-90. https://doi.org/1 0.1016/j.ajic.2015.07.028.

\section{Publisher's Note}

Springer Nature remains neutral with regard to jurisdictional claims in published maps and institutional affiliations.

Ready to submit your research? Choose BMC and benefit from:

- fast, convenient online submission

- thorough peer review by experienced researchers in your field

- rapid publication on acceptance

- support for research data, including large and complex data types

- gold Open Access which fosters wider collaboration and increased citations

- maximum visibility for your research: over $100 \mathrm{M}$ website views per year

At BMC, research is always in progress.

Learn more biomedcentral.com/submissions 